\title{
Efficiency of Processed Farm Wastes on Structure and Oba Super 11 Grain Yield on Condemned Oil Stressed Soil in Southeastern Nigeria
}

\author{
Njoku, C. ${ }^{*}$, Nwite, J.N. ${ }^{1}$, Nwogbaga, A.C. ${ }^{2}$, Nwokwu, G.N. ${ }^{2}$, \\ Akande, O.S. ${ }^{3}$, and Enyioko, C.O. ${ }^{3}$
}

\begin{abstract}
${ }^{1}$ Department of Soil Science and Environmental Management, Faculty of Agriculture and Natural Resources Management, Ebonyi State University Abakaliki, Ebonyi State +234, Nigeria

${ }^{2}$ Department of Crop Science and Landscape Management, Faculty of Agricultural and Natural Resources Management, Ebonyi State University Abakaliki, Ebonyi State, Nigeria

${ }^{3}$ College of Land Resources Technology Owerri, Imo State, Nigeria
\end{abstract}

${ }^{*}$ Corresponding author. E-mail: chimarco2001@yahoo.com https/:doi.org/10.12982/CMUJNS.2020.0019

Received: May 28, 2019

Revised: July 31, 2019

Accepted: August 1,2019

\begin{abstract}
Condemned oil causes a lot of change in the soil structural stabilization leading to significantly loss of its capacity to support crop yield. As a result of this, a research was done in 2015, 2016 and 2017 to evaluate condemned oil stress soil and assess effectiveness of different processed farm wastes in attenuating negative structural changes on soil structure and influence on grain yield. Four treatments: Ash $=15 \mathrm{tha}^{-1}$ of rice mill ash; Fresh $=15 \mathrm{tha}^{-1}$ of fresh rice mill waste; Timber $=15 \mathrm{t} \mathrm{ha} \mathrm{H}^{-1}$ of timer mill waste; Control $=$ Nonapplication of amendment. These treatments were applied on a condemned oil stressed soil. The treatments showed higher significant improvement in Ash with respect to attenuating contamination stress soil structure and higher Oba Super 11 grain yield. Therefore, higher significant structural stabilization and sustainable grain yield of Oba Super 11 can be achieved by application of rice mill ash on condemned oil stress soil.
\end{abstract}

Keywords: Condemned oil stress, Physical properties, Processed farm wastes, Oba Super 11, Soil structure, Yield 


\section{INTRODUCTION}

The world population has been predicted to exceed 10 billion by year 2050 (Food and Agricultural Organization, 1994). One of the herculean tasks facing man now is how to close up food demand gap associated with this geometric rise. The major limitations to high and sustainable agricultural production globally are the environmental stresses consisting of salinity, heavy metals, temperature, drought (Mestre et al., 2012; Onwuka et al., 2012; Naveed et al., 2019) and degradation as well as contamination. Condemned oil contamination is one of the major environmental threats that can initiate negative effects on not only soil structure but agriculture generally especially in tropical areas already endangered by degradation thereby potentially limiting crop yield. Human activities such as car repairs, engine leaks, pipe damage and tractorization have been linked as sources of contamination. Many useful functions of soil structure including nutrient sorption and desorption, water storage and transmission conservation and regulation of heat are jeopardized by condemned oil.

One serious primary effects of condemned oil stress is deterioration of soil structure. The hydrocarbon content increases soil densification leading to crusting, sealing, compaction, doughtiness, loss of stabilization and oxygen stress (Odjuvwederhie, 2006; Kayode, 2009). Thus, there is consequent erosion of surface soil, collapse of structure and massive loss of organic carbon, availability of phosphorus, nitrogen and potassium which concentrated on upper horizon of soil (Odjegba and Sadiq, 2002).

Apart from structural degradation, condemned oil stress has been noted to interfere with physiological processes of a germinating seed and thereby causing unsatisfactory germination. It can also induce poor mineral nutrition of crops, inhibition, complexion, low uptake and transportation or translocation within the crop body (Agbogidi et al., 2006). This condition is known to have caused poor growth, low root expression and feeding which culminated in reduced yield of crops (Jan and Amanulla, 2011).

Processed farm wastes exemplified by rice mill ash and fresh mill wastes are ubiquitous in the ecological area. The wastes have high specific surface and low C: N ratio (Angina et al., 2013). These qualities can be exploited in using it to rehabilitate a structural stressed soil. Rice mill ash can play vital role in improving physically defected soil to its advantages of low lignin, carboxylic and hydroxyl content that can reorient and realign soil particles (Angina et al., 2013). Calcium is a divalent cation and has been adjudged to have capacity to cause flocculation of soil particles (Obi, 2000). Applying any material that can boost its divalent ion content is important for maintaining integrity of soil structure, partitioning, increasing soil voids or gradation and increase aeration status. Overcoming negative impact of soil contamination entails amendment of wastes that can supplement calcium and other valuable materials to growth medium as ameliorative agents (Naveed et al., 2019). 
Oba Super 11 is a hybrid variety of maize which has completely replaced local variety in Nigeria. It is preferred because of its high adaptability, productivity and wide acceptability. The crop is the third most widely cultivated, accounting for more than $30 \%$ arable production (National Programme for Agriculture and Food Security, 2010). Despite the wide cultivation, it has not been able to meet up with the high demand. Cultivation is carried out under tropical environment where structural stressed soil condition due to contamination reduces targeted production to uneconomical level. This study was carried out to evaluate the condemned oil stress and assess effectiveness of different processed farm wastes in attenuating induced negative structural changes on soil structure influence on grain yield of this hybrid crop.

\section{Study area}

\section{MATERIALS AND METHODS}

The study was carried out at Ebonyi State University, Abakaliki and lies on a longitude $6.3367^{\circ} \mathrm{N}-6.01177^{\circ} \mathrm{N}$ and latitude $8.11267^{\circ} \mathrm{E}-8.14136^{\circ} \mathrm{E}$ at elevation of $447 \mathrm{~m}$ above the sea level. Abakaliki is a derived savannah agroecological zone of southeastern Nigeria. The site is characterized with a daily temperature range of $27^{\circ} \mathrm{C}-32^{\circ} \mathrm{C}$. The rainfall regime is bimodal (April-July) and (September-November), with peaks in July and September. The annual rainfall in the area ranges between 1,500-2,000 $\mathrm{mm}$ with mean annual rainfall of $1,800 \mathrm{~mm}$. Humidity is high $(80 \%)$ with lowest $(60 \%)$ occurring during the dry season in April before raining season begins. The soil is hydromorphic and belongs to the order Ultisol within Ezzamgbo soil association, derived from shale and classified as typic Hapludult (Federal Department of Agriculture and Land Resources 1987), which is largely sandy loam and ranging from low to medium fertility, indicating the need for the application of organic or inorganic amendment to its fertility status for crop production.

\section{Experimental design and treatment application}

The study lasted for three cropping seasons $(2015$ - 2017). Field activities commenced from April each year wind up in September for the seasons. Oba Super 11 hybrid variety of maize was used as a plant material. Certified seeds of Zea mays L. were sourced from research institute, IITA, Ibadan, Nigeria. The seed were tested for viability before planting at $25 \mathrm{~cm} \mathrm{X} 75 \mathrm{~cm}$ in the plots contaminated with condemned oil and amended with processed farm wastes. After germination, six plants were tagged and used for the study. The experimental set up was Randomized Complete Block Design (RCBD). 20 kilolitres ha $^{-1}$ of condemned oil was used to contaminate each plot before the application of treatments. Four different treatments were replicated 5 times in a plot of $3 \mathrm{~m} \times 3 \mathrm{~m}$ dimensions namely as shown: 
Ash $\quad=15 \mathrm{tha}^{-1}$ of rice mill ash

Fresh $\quad=15 \mathrm{t} \mathrm{ha}^{-1}$ of fresh rice mill waste

Timber $=15 \mathrm{t} \mathrm{ha}^{-1}$ of timber mill waste

Control = Non-application of amendment. Each plot received 400 $\mathrm{kgha}^{-1}$ of NPK fertilizer dose. At 150 days, cobs were harvested and grain yield assessed at $14 \%$ moisture content.

\section{Soil sample collection}

At the start of the experiment, soil samples were collected with soil auger at $0-20 \mathrm{~cm}$ depth at 15 points within the field. The samples were composited and subsample taken for laboratory determinations (Table 1). At harvest core and auger soil samples were collected at same depth as used before commencement of the study. Core samples were used to evaluate physical properties while auger samples air dried at $26^{\circ} \mathrm{C}$ before using it for laboratory determinations.

Table 1. Some properties of the soil at the beginning of the study.

\begin{tabular}{lll}
\hline \multicolumn{1}{c}{ Soil properties } & Unit & Value \\
\hline Sand & $\mathrm{gkg}^{-1}$ & 560 \\
Silt & $\mathrm{gkg}^{-1}$ & 300 \\
Clay & $\mathrm{gkg}^{-1}$ & 140 \\
Textural class & & Sandy loam (SL) \\
Bulk density & $\mathrm{Mgm}^{-3}$ & 1.66 \\
Total porosity & $\%$ & 37.36 \\
Aggregate stability & $\%$ & 58.6 \\
Mean weight diameter & $\mathrm{Mm}$ & 2.85 \\
& & \\
\hline
\end{tabular}

Particle size distribution: Bouyoucous hydrometer method was used to determine particle size distribution (Gee and Or, 2002) and textural triangle was used to determine textural class of the soil.

Bulk density: Core of $60 \mathrm{~cm}^{3}$ and diameter of $5 \mathrm{~cm}$ was used to collect soil sample. The sample was oven dried at $26^{\circ} \mathrm{C}$ to constant weight. Differences in weight between saturated samples and dried sample. The unit difference in weight (g) between saturated sample and dried one was evaluated by weight of dried sample. The unit is $\mathrm{Mgm}^{-3}$.

Total Porosity: This data was estimated by evaluation of difference in weight $(\mathrm{g})$ between wet and dry samples using volume of soil. It is dimensionless and porosity quantified with percentage.

Aggregate stability: This was estimated with using Kemper and Rosenau method (Kemper and Rosenau, 1986). A nest sieve 0.25, 0.5, 1, and $2 \mathrm{~mm}$ were used to sieve $50 \mathrm{~g}$ of soil sample dropped on the topmost sieve. The sizes of the samples were separated according to diameter range of the sieve sizes. After 
deducting weight $(\mathrm{g})$ of sand alone from that of sand and resistant aggregates $(\mathrm{g})$, the difference was evaluated with the weight of the total sample. Soil samples between 4.76 and $0.25 \mathrm{~mm}$ were used to express WSA $>0.25 \mathrm{~mm}$. The unit is determined in percentage.

Mean weight diameter: Estimation of mean weight diameter was carried out according to Kemper and Rosenau (Kemper and Rosenau, 1986).

\section{Grain yield}

At time of harvest, cobs were taken and grains were removed and weighed before and after sun drying at $14+1^{\circ} \mathrm{C}$ for 96 hours when they attained a constant weight for determination of grain yield of maize.

\section{Statistical analysis}

The data generated were statistically analysed using analysis of variance (ANOVA) to validate the results.

\section{RESULTS}

Particle Size Distribution: Table 2 indicates alteration of particle sizes relative to data before contamination. Size distribution of soil particles was estimated by using the method of Gee and Or (2002). Quantity of $50 \mathrm{~g}$ of sieved and dried soil sample was soaked and latter transferred to volumetric flask of 110 $\mathrm{cm}^{3}$ volume after stirring. Sodium hexametaphosphate was added and particle sizes were evaluated by calculation.

Table 2. Particle Sizes of soil after amendment.

\begin{tabular}{|c|c|c|c|c|c|c|c|c|c|c|c|c|}
\hline \multicolumn{3}{|c|}{2015} & \multicolumn{5}{|c|}{2016} & \multicolumn{3}{|c|}{2017} & \multirow[b]{2}{*}{$\begin{array}{l}\text { Clay } \\
\left(\text { gkg }^{-1}\right)\end{array}$} & \multirow[b]{2}{*}{ Texture } \\
\hline Treatment & $\begin{array}{l}\text { Sand } \\
\left(\text { gkg }^{-1}\right)\end{array}$ & $\begin{array}{l}\text { Silt } \\
\left(\mathrm{gkg}^{-1}\right)\end{array}$ & $\begin{array}{l}\text { Clay } \\
\left(\mathrm{gkg}^{-1}\right)\end{array}$ & Texture & $\begin{array}{l}\text { Sand } \\
\left(\text { gkg }^{-1}\right)\end{array}$ & $\begin{array}{l}\text { Silt } \\
\left(\mathrm{gkg}^{-1}\right)\end{array}$ & $\begin{array}{l}\text { Clay } \\
\left(\mathrm{gkg}^{-1}\right)\end{array}$ & Texture & $\begin{array}{l}\text { Sand } \\
\left(\mathrm{gkg}^{-1}\right)\end{array}$ & $\begin{array}{l}\text { Silt } \\
\left(\text { gkg }^{-1}\right)\end{array}$ & & \\
\hline Control & 610 & 320 & 70 & SL & 680 & 200 & 120 & SL & 750 & 100 & 150 & SL \\
\hline Ash & 560 & 330 & 110 & SL & 490 & 380 & 130 & SL & 650 & 250 & 170 & SL \\
\hline Fresh & 550 & 340 & 110 & SL & 500 & 380 & 120 & SL & 630 & 220 & 150 & SL \\
\hline Timber & 550 & 340 & 110 & SL & 540 & 400 & 110 & SL & 640 & 200 & 160 & SL \\
\hline
\end{tabular}

Note: Ash $=15 \mathrm{t} \mathrm{ha}^{-1}$ of rice mill ash; Fresh $=15 \mathrm{t} \mathrm{ha}^{-1}$ of fresh rice mill waste; Timber $=15 \mathrm{t} \mathrm{ha}^{-1}$ of timer mill waste; Control = Non-application of amendment, $\mathrm{SL}=$ Sandy loam. 
Table 3. Influence of amendments on bulk density $\left(\mathrm{Mgm}^{-3}\right)$ and total porosity.

\begin{tabular}{lcccccc}
\hline & $\begin{array}{c}\mathbf{2 0 1 5} \\
\text { Bulk density } \\
\left(\mathbf{M g m}^{-3}\right)\end{array}$ & $\begin{array}{c}\text { Total } \\
\text { Porosity }(\%)\end{array}$ & $\begin{array}{c}\mathbf{2 0 1 6} \\
\text { Bulk density } \\
\left(\mathbf{M g m}^{-3}\right)\end{array}$ & $\begin{array}{c}\text { Total } \\
\text { porosity }(\%)\end{array}$ & $\begin{array}{c}\text { 2017 } \\
\text { Bulk density } \\
\left(\mathbf{M g m}^{-3}\right)\end{array}$ & $\begin{array}{c}\text { Total } \\
\text { porosity (\%) }\end{array}$ \\
\hline Control & 1.68 & 36.60 & 1.70 & 35.85 & 1.73 & 34.72 \\
Ash & 1.55 & 41.51 & 1.58 & 40.38 & 1.60 & 39.62 \\
Fresh & 1.62 & 38.87 & 1.65 & 37.84 & 1.66 & 37.36 \\
Timber & 1.65 & 37.84 & 1.66 & 37.36 & 1.67 & 36.98 \\
\hline LSD & 0.03 & 2.05 & 0.02 & 1.98 & 0.03 & 1.81 \\
\hline
\end{tabular}

Note: Ash $=15 \mathrm{t} \mathrm{ha}^{-1}$ of rice mill ash; Fresh $=15 \mathrm{t} \mathrm{ha}^{-1}$ of fresh rice mill waste; Timber $=15 \mathrm{t} \mathrm{ha}^{-1}$ of timer mill waste; Control = Non-application of amendment.

Table 4. Influence of amendments on aggregate stability (\%).

\begin{tabular}{llll}
\hline Treatment & $\mathbf{2 0 1 5}$ & $\mathbf{2 0 1 6}$ & $\mathbf{2 0 1 7}$ \\
\hline Control & 52.5 & 50.0 & 42.0 \\
Ash & 68.0 & 62.6 & 45.0 \\
Fresh & 65.4 & 60.2 & 44.0 \\
Timber & 60.6 & 56.3 & 54.1 \\
\hline LSD $(0.05)$ & 4.6 & 7.6 & 1.4
\end{tabular}

Note: Ash $=15 \mathrm{t} \mathrm{ha}^{-1}$ of rice mill ash; Fresh $=15 \mathrm{t} \mathrm{ha}^{-1}$ of fresh rice mill waste; Timber $=15 \mathrm{t} \mathrm{ha}^{-1}$ of timer mill waste; Control $=$ Non-application of amendment.

Table 5. Influence of amendments on mean weight diameter ( $\mathrm{mm})$.

\begin{tabular}{llll}
\hline Treatment & $\mathbf{2 0 1 5}$ & $\mathbf{2 0 1 6}$ & $\mathbf{2 0 1 7}$ \\
\hline Control & 2.50 & 2.20 & 2.10 \\
Ash & 3.00 & 3.80 & 2.70 \\
Fresh & 2.80 & 2.50 & 2.65 \\
Timber & 2.85 & 2.60 & 2.50 \\
\hline LSD $(0.05)$ & 0.14 & 0.10 & 0.13 \\
\hline
\end{tabular}

Note: Ash $=15 \mathrm{t} \mathrm{ha}^{-1}$ of rice mill ash; Fresh $=15 \mathrm{t} \mathrm{ha}^{-1}$ of fresh rice mill waste; Timber $=15 \mathrm{t} \mathrm{ha}^{-1}$ of timer mill waste; Control $=$ Non-application of amendment. 
Table 6. Influence of amendments on grain yield of maize $\left(\mathrm{t} \mathrm{ha}^{-1}\right)$.

\begin{tabular}{lccc}
\hline Treatment & $\mathbf{2 0 1 5}$ & $\mathbf{2 0 1 6}$ & $\mathbf{2 0 1 7}$ \\
\hline Control & 1.20 & 1.18 & 1.14 \\
Ash & 1.62 & 1.58 & 1.52 \\
Fresh & 1.60 & 1.56 & 1.53 \\
Timber & 1.52 & 1.52 & 1.42 \\
\hline LSD $(0.05)$ & 0.05 & 0.04 & 0.09
\end{tabular}

Note: Ash $=15 \mathrm{tha}^{-1}$ of rice mill ash; Fresh $=15 \mathrm{tha}^{-1}$ of fresh rice mill waste; Timber $=15 \mathrm{tha}^{-1}$ of timer mill waste; Control $=$ Non-application of amendment.

Particle Size Distribution: It was observed that particle size distribution obtained after the treatment did not vary much from the initial data (Table 2). Major change in clay content $\left(170 \mathrm{gkg}^{-1}\right)$ was recorded in Ash with respect to control $\left(140 \mathrm{gkg}^{-1}\right)$ and other treatments $\left(150-160 \mathrm{gkg}^{-1}\right)$. Generally, sand fraction appreciated in control relative to treated plots. Silt fractions were relatively higher in amended plots compared to Control.

Bulk Density: The bulk density of Ash showed non-significant change between control and other treatments. Compared to initial data $\left(1.66 \mathrm{Mgm}^{-3}\right)$ bulk densities ranged from $1.55-1.58 \mathrm{Mgm}^{-3}$ for amended seasons and $\mathrm{Mgm}^{-3} 1.60$ $\mathrm{Mgm}^{-3}$ for residual study. This account accounted for 8, 9 and $8 \%$ reduction. The bulk density recorded between Fresh and Timber were significantly inferior except in first season $\left(1.62-1.65 \mathrm{Mgm}^{-3}\right)$, respectively. It was discovered that bulk densities of control were higher significantly during periods of experiment and residual time compared with those of condemned oil stressed soil receiving treatments. Highest bulk density was obtained in Timber treated plots in residual season.

Total Porosity: Initial data (37.36\%) in Table 3 indicated $0.07,1.51$ and $2.64 \%$ degradation of total porosities for the periods (41.51 and $40.38 \%$ ) and $39.62 \%$ were obtained for Ash treated plots compared with Fresh and Timber treatments during application of wastes than in residual. Control values (36. 60 and $35.80 \%$ ) and $34.72 \%$ significantly decreased relative to amendments. Furthermore, total porosities of Fresh and Timber were significantly inferior over the periods. It was noted that the total porosities were reduced as time progressed giving least value (36.98\%) in plot treated with Timber.

Aggregate Stability: Aggregate stabilities were significantly reduced by $6.1,8.6$ and $16.6 \%$ for the three seasons of the study relative to the initial value (58.6\%). Aggregate stabilities 52.5, 50.0 and 42.0\% were observed in Ash amended plot during the intervening periods with respect to control and plots amended with Fresh and Timber, respectively. This amounted to 23 and 20\% increments in aggregate stability for Ash compared to Control. Timber differed 
significantly in aggregate stabilities recorded considering their values in first season (65.4 and 60.6\%) and residual assessment (44.0 and 54.1\%). There were considerable significant reductions in aggregate stabilities of control with least $(42.0 \%)$ in residual.

Mean Weight Diameter: Condemned oil degraded mean weight diameter by $0.35 \mathrm{~mm}$ for first season, $0.65 \mathrm{~mm}$ for second season and $0.75 \mathrm{~mm}$ for residual compared to initial. Maxmum significant MWD of data of $2.85 \mathrm{~mm}$ and $3.00 \mathrm{~mm}$ was obtained in Ash for first season, $3.80 \mathrm{~mm}$ for second season and $2.70 \mathrm{~mm}$ for third season compared to plots amended with Fresh and Timber. This resulted to $7-5 \%, 11-7 \%$ and $2-7 \%$ increments in MWD relative to Fresh and Timber for the periods. Mean weight diameter showed marginal significant changes during the second year as well as residual. The plots receiving processed farm wastes significantly differed from control $(2.50,2.20$ and $2.10 \mathrm{~mm})$ throughout the intervening periods.

Grain Yield: The grain yields were 1.62, 1.58 and 1.52 tha $^{-1}$ for Ash for the seasons and significantly different from those of Timber which recorded 1.52, 1.52 and 1.42 tha $^{-1}$. The plot amended with processed farm wastes had significant higher grain yields for the seasons compared to control $\left(1.20,1.18,1.14\right.$ tha $\left.^{-1}\right)$. Grain yields showed progress reductions with seasons recording least values of 1.14tha ${ }^{-1}$ for Control, 1.52tha ${ }^{-1}$ for Ash, 1.53 tha $^{-1}$ for Fresh and 1.42tha ${ }^{-1}$ for Timber, respectively.

\section{DISCUSSION}

The ultimate interest of every farmer occupies a central position in soil productivity (Busemeyer et al., 2013). It is a major indicator of crop stressed soil tolerance (Naveed et al., 2019). Grain yield of Oba Super 11 declined significantly during the application of condemned oil residual. The decrease in grain yield can be linked to degradation in soil structure and stress induced condition due to contamination (Gwenzi et al., 2016). Significant increments in grain yield after processed farm wastes amendment suggests the capacities of these amendments to attenuate the adverse effects of condemned oil stress. These findings were in consonance with earlier reports with regards to application of organic wastes on oil stressed soil. The maximum significant grain yield recorded in stressed soil amended with Ash was attributed to efficiency of the processed material in amelioration of stressed condition grain yield of maize. This positive effect on yield was predicted on its substantially improving quality of soil structure (Table 3-5). Furthermore, condemned oil affected particle size distribution (PSD) which reduced efficiency of soil in crop nutrient exchanges and proper anchorage resulting to lodging. These negative influences on PSD were largely implications of stressed condition. Poor sorption-desorption of nutrients and lack of firm rooting reduced crop nutrition and consequent poor yield. Result obtained resembled finding of alteration of PSD under oil stress 
condition (Agbogidi et al., 2006). Processed farm wastes treatments alleviated PSD of soil with peak in the application of rice mill ash. The $C: N$ ratio facilitated comparable faster decomposition of the waste releasing aliphatic aromatic compounds which had positive effect on particle size reconfiguration of the but not on texture. Bulk densities regarded as one of the indicators of soil structure increased in condemned oil stress plots. The higher significant levels of bulk densities could be related to compaction of soil caused by oil stressed condition. However, application of processed farm wastes restored density of soil, the higher potential was exhibited by treatment of Ash suggesting greater efficiency in restoration of degraded bulk density. This finding is supported by lower bulk densities obtained in degraded plots treated with rice mill ash (Angina et al., 2013). Ash material contains much higher calcium content (Quni et al., 2014) and for that acts as soil conditioner. Condemned oil interfered with pore configuration of soil leading to significant reductions in porosity during the study. This was possible because its degradative effect on soil density (Molina-Herrera and Romanya, 2015). Processed farm wastes treatments reversed the negative effect, the higher potential being evidenced in rice mill ash amendment suggesting more superiority in reclaiming porosity stress soil. The treatment loosened soil and created pathways for increased porosity. Finding agrees with increased total observed in heavy metals stressed soil which was reclaimed with organic wastes. Aggregate stability is a major index of soil structural stabilization. In this study, condemned oil contamination had significant reduction effect on aggregate stability during the experiment. The application of processed farm wastes alleviated the deleterious effect with rice mill ash amendment having sustainable effects (Asai et al., 2009) except residual investigation increased and sustainable aggregate stability where rice mill ash was applies had been reported (Liang et al., 2010). This salvaging effect of rice mill ash treatment was attributed to calcium content of ash material which has advantage of coagulation effect on soil particles (Eibisch et al., 2015). Condemned oil stress had profound degradation effect on mean weight diameter, one of the major determinants of quality of soil structure. Although, processed farm wastes enhanced MWD during their application but not beyond limiting levels (Anikwe, 2006), except rice mill ash. This comparative advantage was hinged on its efficiency in combating condemned oil induced structural degradation. Efficiency of rice mill ash on MWD to structural stabilization is as a result of lower sodium content (Kolay, 2013). Sodium ion plays vital role as soil dispersant agent. Condemned oil stress interferes with cohesive and adhesive force operating at soil interface. This reduced soil cohesion and destabilization indices of soil structure.

Assessing the treatments individually, rice mill ash amendment proved more efficient than fresh rice mill wastes and timber mill wastes applications which may be the unique role in interfering with degradative tendencies of alpha aromatic ring compounds at redox surfaces thereby stabilizing soil parts by linking soil particles. This forms superior positive effect of rice mill ash on soil 
physical properties earlier reported in study where biochar was applied on environmentally stressed soil (Kolay, 2013). In line with the current study, incorporating rice mill ashes function as a binding agent that connected microaggregates to form macroaggregates (Liu et al., 2012). The oxidized surfaces of rice mill ash such as hydroxyl groups and carboxylic groups adsorbed soil particles and clays to form macroaggregates (Jein and Wang, 2013). It had been noted that additions of ash materials can substantially increase aggregate sizes and stabilized the soil (Brockhoff, et al. 2010). Several works have been conducted on effectiveness of amended farm wastes to restore degraded soil physical properties such as bulk density, total porosity, aggregate stability and mean weight diameter and they gave firm confirmation of results of present study (Mahmoodabadi et al., 2013; Mamedov et al., 2014; Hossain et al., 2017). Improved aggregation and to a large extent soil structure emanate from cationic bridge provided by the processed farm wastes which was skewed in rice mill ash (Pagliai et al., 2004). Similarly, the increase soil structural indices recorded after treatments of processed farm wastes by many workers during a study of erosion stress soil (Dexter, 2002) and stress are consonant with the report of this investigation.

\section{CONCLUSION}

Condemned oil stress degrades soil structure and lowers productivity to a considerable extent. The major effect of contamination induced stress in soil is the deterioration of structural indices. The structural stabilization and quality as well as productivity of condemned oil stressed soil structure can be improved by application of rice mill ash. This ash indicated a more significant potential in attenuating the oil induced stress than other amendments by providing sufficient hydroxyl and carboxylic groups cationic bridges which acted as defense mechanism.

\section{ACKNOWLEDGEMENTS}

The authors wish to thank those who assisted directly or indirectly to bring this study to the level it is today. Top on the list are the staff of Soil Science Laboratory Ebonyi State University, Ebonyi State Nigeria. Our regards also, go to the staff of Soil Science and Crop Science Laboratories of National Root Crop and Research Institute Umudike, who helped us in the laboratories analyses of this study. We also, thank some of our colleagues in the Department of Soil Science and Environmental Management who assisted us in one way or the other to make this research a success. 


\section{REFERENCES}

Agbogidi, O.M., Eruotor, P.G., Akparobi, S.O., and Nnaji, G.U. 2006. Yield performance of five cultivars of Soyabean (Glycine $\max (\mathrm{L})$. Merr.) as influenced by soil contaminated with crude oil. Nigerian Journal of Tropical Agriculture. 8: 303-309.

Angina, I., Aksakal, E.L., Oztas, T., and Handy, A. 2013. Effects of municipal solid waste compost (MSWC) application on certain physical properties of soils subjected to freeze-thaw. Soil and Tillage Research. 130: 58-61. https://doi.org/10.1016/j.still.2013.02.009

Anikwe, M.A.N. 2006. Soil quality assessment and monitoring: a review of current research efforts. Enugu, Nigeria: New generation books, New Generation Ventures Ltd.

Asai, H., Sampson, B.J., Stephan, H.M., Singyikhangsuther, K., Homma, K.K., Kiyono, V., Inoue, Y., Shirsiwa, T., and Horie, T. 2009. Biochar amendment techniques for upland rice production in Northern Laos I. soil physical properties, leaf SPAD and grain yield'. Field Crops Research. 111(1-2): 8184. https://doi.org/10.1016/j.fcr.2008.10.008

Brockhoff, S.R., Christian, N.E., Killom, R.J., Horton, R., and Davis, D.D. 2010. Physical and mineral-nutrition properties of sand-base turf grass root zones amended with biochar. Agronomy Journal. 102: 1627-1631. https://doi. org/10.2134/agronj2010.0188

Busemeyer, L.A., Ruckelshausen, K., Moller, K., Melchingerand, A.E., and Alheit, K.V. 2013. Precisionp phenotyping of biomass accumulation in triticate reveals temporal genetic patterns of regulation. Scientist Report. 3 (10): 2442. https://doi.org/10.1038/srep02442

Dexter, A.R. 2002. Soil structure: the key to soil function. Advance GeoEcology. 35: 57-69.

Eibisch, N., Durner, W., Benchtold, M., Fuss, R., Mikutta, R., Woche, S.K., and Helfrich, M. 2015. Does water repellency of pyrochars and hydrochars counter their positive effects on soil hydraulic properties? Geoderma. $245-$ 246: 31-39. https://doi.org/10.1016/j.geoderma.2015.01.009

Federal Department of Agriculture and Land Resources. 1987. Reconnaissance soil survey of Anambara state Nigeria. Soil Report FDALR, Kaduna.

Food and Agricultural Organization. 1994. Soil management for sustainable agriculture and environmental protection in the tropics. Land and Water Development Division, Food and Agriculture Organization of the United Nations, Viale delle Terme di Caracalla Rome, Italy.

Gee, G.W., and Or, D. 2002. Particle size analysis. In: Dane, J.H., and Topp. G.C., editors. Methods of soil analysis, physical methods. Soil Science Society of America. 5: 255-293. 
Gwenzi, W., Muzava, M., Mepanda, F., and Tauro, T.P. 2016. Comparative short-term effects of sewage sludge and its biochar on soil properties, maize growth and uptake of nutrients on a tropical clay soil in Zimbabwe. Journal of Integrated Agriculture. 15: 1395-1406. https://doi.org/10.1016/S20953119(15)61154-6

Hossain, M.Z., Fragstein, P.V., and Sdorff, J.H.N. 2017. Effect of different organic wastes on soil properties and plant growth and yield. Scientia Agricultural Bohemica. 48(4): 224-237. https://doi.org/10.1015/sab-20170030

Jan, A., and Amanulla, M.N. 2011. Wheat response to farm yard manure and nitrogen fertilization under moisture stress conditions. Journal of Plant Nutrition. 34: 732-742. https://doi.org/10.1080/01904167.2011.540688

Jein, S.H., and Wang, C.S. 2013. Effects of biochar on soil properties and erosion potential in a highly weathered soil. Catena. 110: 225-233. https://doi.org/ 10.1016/j.catena.2013.06.021

Kayode, J., Oyedeji, A.A., and Olowoyo, O. 2009. Evaluation of the effect of pollution with spent lubricant oil on the physical and chemical properties of soil. Pacific Journal of Science and Technology. 10(1): 387-391.

Kemper, W.D., and Rosenau, R.C. 1986. Aggregate stability and size distribution. In: Klute A., editor. Methods of soil analysis, Part 1. American Society of Agronomy. 9: 425 -440.

Kolay, A.K. 2013. Basic concepts of soil science. India: New Age International Publishers Ltd.

Liang, B.Q., Lehmann, J., Sohi, S.P., Thies, J.E., O’Neill, B., Trujillo, L., Craut, J., Solomon, D., Grossman, J., Neves, E.G., et al. 2010. Black carbon affects the cycling of non-black carbon in soils. Organic Geochemical. 41: 206-213. https://doi.org/10.1016/j.orggeochem.2009.09.007

Liu, X.H., Han, F.P., and Zhang, X.C. 2012. Effects of biochar on soil aggregates in the loes plateui results from incubation experiments. International Journal of Agriculture and Biology. 14: 975-979.

Mahmoodabadi, M., Yazadanpanah, N., Sinobag, L.R., Pazira, E., and Neshat, A. 2013. Reclamation of calcareous saline sodic soil with different amendments (1): redistribution of soluble cations within the soil profile. Agricultural Water Management. 120: 30-38. https://doi.org/10.1016/ j.agwat.2012.08.018

Mamedov, A.L., Bar-yosef, B., Levkovich, I., Rosenberg, R., Silber, A., Fine, P., and Levey, G.J. 2014. Amending soil with sludge, manure, humic acid, orthophosphate and phylic acid: effects on aggregate stability. Soil Research. 52(4): 317-326. https://doi.org/10.1071/SR13334

Mestre, T.C., Coarcia-Sanchez, F., Rubio, F., Martinez, V., and Rivero, R.M. 2012. Glutathione homeostasis as an important and novel factor controlling blossom-end rot development in calcium-deficient tomato fruits. Journal of Plant Physiology. 169: 1719-1727. 
Molina-Herrera, S., and Romanya, J. 2015. Synergistic and antagonistic interactions among organic amendments of contrasted stability, nutrient availability and soil organic matter in the regulation of $\mathrm{C}$ mineralization. European Journal of Soil Biology. 70: 118-125. https://doi.org/10.1016/ j.ejsobi.2015.09.001

National Programme for Agriculture and Food Security. 2010. Federal Ministry of Agriculture and Rural Development. Report of the Agricultural Production Survey, Abujah, FCT, Nigeria.

Naveed, G. Y., Mohammed, M., and Saima, H. 2019. Effect of nitrogen and phosphorus on the growth and redox homeostasis of salt-stressed mustard plants. Asian Journal of Plant Science. 18(2): 52-59. https://doi.org/ 10.3923/ajps.2019.52.59

Obi, M.E. 2000. Soil physics. compendium of lectures. Nigeria: Atlanto, Nsukka, Publishers.

Odjegba, V.J., and. Sadiq, A.O. 2002. The environmentalist. Effect of spent engine oil on the growth parameters, chlorophyll and protein levels of Amaranthus hybridus L. Journal of Environmental Science. 22(1): 23-28.

Odjuvwederhie, E.I., Doughason, G.O., and Adun, F.N. 2006. The effect of oil spillage on crop and farm income in Delta State. Nigeria Journal of Central European Agriculture. 7(1): 41-48.

Onwuka, M.I., Chude, G.O., and Ogwuegbu, G.C. 2012. Remediation of spent engine oil polluted soil using two types of organic manure and their effects on maize growth. Nigerian Journal of Soil Science. 22(2): 245-252.

Quni, Y., Albacete, A., Cantero, E., Lakhdar, A., Abdally, C., Perez-Alfocea, E., and Barhoumi, Z. 2014. Influence of municipal solid wastes (MSW) compost on hormonal status and biomass partitioning in two forage species growing under saline soil conditions. Ecology Engineering. 64: 142-150. https://doi.org/10.1016/j.ecoleng.2013.12.053

Pagliai, M., Vignozzi, N., and Pellegrini, S. 2004. Soil structure and the effect of management practices. Soil and Tillage Research. 79: 131-143. https://doi. org/10.1016/j.still.2004.07.002 